\title{
PENGARUH VOLUME PERDAGANGAN SAHAM DAN HARGA SAHAM TERHADAP BID-ASK SPREAD STUDI PADA PERUSAHAAN-PERUSAHAAN MANUFAKTUR YANG TERDAFTAR DI BURSA EFEK INDONESIA
}

\author{
Ruminsar Nainggolan \\ Dr. Donalson Silalahi
}

\begin{abstract}
The purpose of this study is to determine the effect of stock trading volume and stock prices on bid-ask spreads on manufacturing companies listed on the Indonesia Stock Exchange. The population in research is 155 companies and by using purposive sampling as sampling technique, then the sample in this research is 46 company. The data used are secondary data and use multiple regression equation as an analytical tool.

Based on the results of the research it can be argued that, trading volume and stock prices have a negative and significant effect on the bid-ask spread both before and after the data grouping. The results also show that stock trading in Indonesia Stock Exchange is liquid.

Investors or potential investors who want to invest in the capital market should make trading volume and stock price as a reference in making investment decisions, because simultaneously these two variables have a significant effect on bid-ask spreads.
\end{abstract}

Keywords: Liquidity, Trade Volume, Stock Price and Bid-Ask Spread.

\section{PENDAHULUAN}

Pada umumnya investor membutuhkan informasi dalam melaksanakan aktivitas perdagangan saham. Salah satu jenis informasi tersebut adalah besaran biaya transaksi dalam mekanisme perdagangan. Teori yang mempelajari biaya transaksi dalam mekanisme perdagangan saham dikenal dengan teori Market Microstructure (O'Hara: 1995; Harris: 2004; Hasbrouck : 2007).

Biaya transaksi dimaninvestasikan oleh besaran bid-ask spread. Besaran bid-ask spread pada dasarnya memiliki elemen informasi asimetri. Oleh karenanya, pelaku pasar yang uninformed menghadapi risiko jika bertransaksi dengan pelaku pasar yang informed. Untuk meminimalkan risiko tersebut, maka pelaku pasar melebarkan bid-ask spread (Aida, 2002). Besaran bid-ask spread sering dipergunakan sebagai proksi tingkat likuiditas pasar. Oleh karena itu, sangat penting diketahui besaran bid-ask spread dalam mekanisme perdagangan dalam menjelaskan likuiditas.

Likuiditas pasar saham dapat dijelaskan secara langsung maupun secara tidak langsung. Pengukuran likuiditas secara langsung dapat diketahui melalui besaran bid-ask spread, sedangkan pengukuran likuiditas secara tidak langsung dapat dijelaskan melalui hubungan antara bid-ask spread dengan volume perdagangan.

Hasil-hasil penelitian menunjukkan bahwa hubungan kausal antara volume perdagangan dengan bid-ask spread tidak konsisten. Tanner (1971); Atkins and Dyl (1997); Ambarwati (2003); Magdalena dan Nany (2003); Chabchitrchaidol dan Panyanukul (2005); Ambarwti (2008); Ciptaningsih (2010) menunjukkan bahwa volume perdagangan berpengaruh negatip terhadap bid-ask spread.

Selain hasil penelitian tersebut, beberapa hasil penelitian lain menunjukkan bahwa volume perdagangan berpengaruh positip terhadap spread. Hal ini didukung oleh penelitian yang dilakukan oleh Fleming dan Remolona (1997); Balduzii et al. (2001) Chandra (2003). Selain hasil-hasil penelitian tersebut diatas, ada juga penelitian yang menyatakan bahwa volume perdagangan tidak berpengaruh signifikan terhadap bid-ask spread, seperti penelitian yang dilakukan oleh Bessembinder et al. (2005); Silalahi (2008). 
Berdasarkan hasil-hasil penelitian tersebut di atas, maka sangat penting dilakukan penelitian lanjutan tentang pengaruh volume perdagangan saham terhadap bid-ask spread di Bursa Efek Indonesia. Selain mempergunakan volume perdagangan saham sebagai variabel bebas, dalam penelitian ini juga dipergunakan harga saham sebagi variabel bebas dalam menjelaskan bid-ask spread.

Menurut Keown et al (2010:376), bahwa spread akan lebih besar untuk mata uang yang jarang diperdagangkan. Hal ini mengindikasikan bahwa tingginya harga dapat mengurangi permintaan. Sama halnya dengan saham, ketika saham terlalu mahal maka saham tersebut akan jarang diperdagangkan atau saham menjadi kurang likuid, sehingga menyebabkan spread melebar karena risiko untuk saham tersebut lebih besar. Artinya harga saham berpengaruh positif terhadap bid - ask spread, hal ini didukung penelitian yang dilakukan oleh Aiten dan Frino (1996); Napitupulu (2013).

Ketika harga saham naik maka bersamaan dengan itu bid - ask spread saham juga akan mengalami penurunan. Hal ini menyatakan bahwa harga saham berpengaruh negatif dan signifikan terhadap bid ask spread dan pernyataan ini didukung oleh penelitian yang dilakukan oleh Nany (2003); Chandra (2003) ; Ciptaningsih (2010).

Selain hasil-hasil penelitian terdahulu bahwa harga saham berpengaruh negatif terhadap spread dan harga saham berpengaruh positip terhadap spread ada juga penelitian yang menyatakan bahwa harga saham tidak berpengaruh signifikan terhadap bid-ask spread, seperti penelitian yang dilakukan oleh Nany dan Aris (2004); Yuliastari (2008).

Berdasarkan hasil-hasil penelitian terdahulu tentang bid-ask spread, peneliti ingin melakukan penelitian kembali tentang pengaruh volume perdagangan dan harga saham terhadap bid-ask spread pada perusahaan manufaktur yang terdaftar di Bursa Efek Indonesia periode Januari - Desember 2015. Perbedaan penelitian ini dengan penelitian terdahulu terletak pada tahun dan objek penelitian serta juga dilakukan pengelom 1 lata berdasarkan volume perdagangan.

Berdasarkan paparan tersebut, maka penelitian ini bertujuan untuk menjelaskan pengaruh volume perdagangan dan harga saham terhadap bid-ask spread pada perusahaan manufaktur yang terdaftar di Bursa Efek Indonesia.

\section{Theory Market Microstrucuture}

\section{TINJAUAN PUSTAKA DAN HIPOTESIS}

O'Hara (1995) menyatakan bahwa market microstructure membahas bagaimana harga aset terbentuk di pasar dengan aturan perdagangan yang ada. Harris (2004) menyatakan bahwa market microstructure merupakan sebuah cabang ilmu ekonomi finansial yang melakukan penyelidikan perdagangan saham dan organisasi pasar.

Penelitian mengenai microstructure dapat dikelompokkan menjadi dua aliran. Pertama, spread models, merupakan studi mengenai perbedaan nilai dari dua struktur pasar yang berbeda, dan mengkaji faktor-faktor penentu besarnya bid - ask spread. Kedua, price formation models, merupakan studi mengenai bagaimana hubungan antara trade size, trading volume dan price level. Dan model yang akan digunakan dalam penelitian ini adalah spread models.

Menurut Bodie et al. (2006:94), bid-ask spread merupakan selisih antara harga penawaran dan permintaan dealer. Harga beli (bid price) merupakan harga yang ingin ditawarkan oleh dealer untuk sebuah sekuritas; harga jual (ask price) merupakan harga yang diminta oleh dealer yang ingin menjual sebuah sekuritas. Besar kecilnya spread dipengaruhi oleh tiga faktor, yaitu: order processing cost, inventory control cost dan adverse selection cost. Oleh karena itu, besaran spread menggambarkan tingkat likuiditas.

\section{Teori Likuiditas Saham}


Menurut Harris (2003), dalam menjelaskan likuiditas ada beberapa dimensi yang perlu diperhatikan yaitu : immediacy, width, depth, dan resiliency. Dimensi immediacy adalah kecepatan atau kemudahan untuk bertransaksi dengan segera dalam jumlah dan harga tertentu. Dimensi width adalah selisih antara harga jual terbaik dengan harga beli terbaik atau dikenal dengan spread. Dimensi yang ketiga adalah depth, merupakan jumlah transaksi yang dapat dilaksanakan pada tingkat harga tertentu tanpa mempengaruhi harga. Dimensi resiliency adalah seberapa cepat harga dapat kembali pada tingkat yang semestinya jika terjadi arus order beli dan order jual yang tidak seimbang.

Dari konsep dimensi diatas, maka likuiditas pasar sekuritas dapat diterangkan secara langsung dan tidak langsung. Spread atau biaya transaksi dalam mekanisme perdagangan yang relatif murah mengidikasikan bahwa pasar saham adalah likuid. Sebaliknya, spread atau biaya transaksi yang relatif mahal dalam mekanisme perdagangan mengindikasikan bahwa pasar saham tidak likuid. Selanjutnya, likuiditas pasar saham dapat juga dijelaskan dengan melihat dampak dari variabel lainya terhadap spread, seperti: dampak volume perdagangan terhadap spread dan dampak harga saham terhadap spread.

\section{Pengaruh Volume Perdagangan Saham terhadap Spread}

Volume perdagangan saham merupakan suatu instrumen yang dapat digunakan untuk melihat reaksi pasar terhadap informasi melalui parameter volume saham yang diperdagangkan di pasar (Sutrisno, 2000). Lebih lanjut, Nany (2003) menyatakan volume perdagangan yang besar mengindikasikan bahwa saham tersebut aktif diperdagangkan. Apabila suatu saham aktif diperdagangkan, artinya dealer tidak lama menyimpan saham tersebut yang mengakibatkan menurunnya tingkat bid-ask spread saham.

Menurut Arifin (2005:161-162), kompensasi yang diterima oleh market maker atas jasa likuiditas sekuritas adalah dalam bentuk bid - ask spread yaitu perbedaan antara harga kuotasi beli dan harga kuotasi jual sekuritas. Secara konseptual, bid - ask spread pada pasar sekuritas merupakan kompensasi ekonomis yang diberikan kepada market maker untuk mendorong mereka agar tetap mau memberikan layanan likuiditas. Market maker diharapkan selalu siap menjual sekuritas ketika ada orang yang mau beli dan siap membeli ketika ada orang yang menjual sekuritas.

Oleh karena itu dapat dikemukakan bahwa volume perdagangan berpengaruh negatif dan signifikan terhadap bid- ask spread. Hal ini didukung hasil penelitian yang dilakukan oleh Fleming dan Remolona (1997); Balduzii et al. (2001); dan Ardha Chandra (2003).

Jika volume perdagangan yang terjadi di pasar saham hanya sedikit akan membuat dealer lebih lama menyimpan saham tersebut dan akan membuat spread tinggi, dalam hal ini dapat disimpulkan bahwa volume perdagangan berpengaruh positip dan signifikan terhadap bid-ask spread. Hal ini didukung hasil penelitian yang dilakukan oleh Tanner (1971); Atkins and Dyl (1997); Ambarwati ((2003); Magdalena dan Nany (2003); Chabchitrchaidol dan Panyanukul (2005); Ambarwti (2008); Ciptaningsih (2010).

\section{Pengaruh Harga Saham terhadap Bid-Ask Spread}

Menurut Sartono (2001:141), saham merupakan nilai sekarang atau present value dari aliran kas yang diharapkan akan diterima di masa depan. Konsep ini menggambarkan nilai intrinsik atau nilai teoritis. Selain nilai intrinsik dikenal juga nilai pasar. Nilai pasar adalah nilai saham di pasar, yang ditunjukkan oleh harga saham tersebut di pasar. Dalam membeli atau menjual saham, investor akan membandingkan nilai intrinsik dengan nilai pasar saham bersangkutan.

Jika nilai pasar suatu saham lebih tinggi dari nilai intrinsiknya, berarti saham tersebut tergolong mahal (overvalued). Sebaliknya jika nilai pasar saham di bawah nilai intrinsiknya, 
berarti saham tersebut tergolong murah (undervalued), sehingga dalam situasi ini investor biasanya membeli saham tersebut (Tandelilin, 2001:183-184).

Keown et al (2010:376) berpendapat bahwa spread akan lebih besar untuk mata uang yang jarang diperdagangkan. Hal ini mengindikasikan bahwa tingginya harga dapat mengurangi permintaan. Sama halnya dengan saham, ketika saham terlalu mahal maka saham tersebut akan jarang diperdagangkan atau saham kurang likuid yang menyebabkan spread semakin besar karena risiko saham tersebut semakin besar. Artinya harga saham berpengaruh positif terhadap bid - ask spread. Konsep ini didukung hasil penelitian yang dilakukan oleh Aiten dan Frino (1996); Napitupulu (2013)

Ketika harga saham naik maka bersamaan dengan itu bid - ask spread saham juga akan mengalami penurunan. Hal ini menyatakan bahwa harga saham berpengaruh negatif terhadap bid-ask spread dan pernyataan ini didukung hasil penelitian yang dilakukan oleh Nany (2003); Chandra (2003) ; Ciptaningsih (2010).

\section{METODOLOGI PENELITIAN}

Variabel yang digunakan dalam penelitian ini adalah bid ask spread, volume perdagangan dan harga saham. Bid-ask spread merupakan biaya yang dikeluarkan dalam mekanisme perdagangan saham yang dihitung dengan mempergunakan rumus berikut :

dimana, $\quad$ BAS $=$ Bid-Ask Spread

$$
\mathrm{BAS}=\frac{\mathrm{Pa}-\mathrm{Pb}}{\mathrm{Pa}+\mathrm{Pb} / 2}
$$

$\mathrm{Pa} \quad=$ Ask price (harga kuotasi jual)

$\mathrm{Pb} \quad=$ Bid price (harga kuotasi beli)

Volume perdagangan saham adalah jumlah saham masing-masing perusahaan yang diperdagangkan setiap hari dalam pasar saham. Harga saham adalah harga saham penutupan (closing price) setiap hari.

Populasi yang digunakan pada penelitian ini adalah semua perusahaan-perusahaan manufaktur yang terdaftar di Bursa Efek Indonesia (BEI) pada periode Januari - Desember 2015 yaitu sebanyak 155 perusahaan. Teknik pengambilan sampel dalam penelitian ini dilakukan dengan cara purposive sampling. Oleh karena itu, sampel yang digunakan dalam penelitian ini adalah 46 perusahaan dengan jumlah pengamatan adalah 7.411. pengamatan.

Data yang digunakan dalam penelitian ini adalah data sekunder, yaitu data yang diperoleh dari daily trading untuk perusahaan-perusahaan manufaktur yang dipulikasikan oleh Bursa Efek Indonesia (BEI).

Teknik analisis data yang digunakan dalam penelitian ini adalah analisis regresi berganda dengan bantuan software SPSS (Statistical Package Social Science) dengan model sebagai berikut.

$$
\mathrm{BAS}=\mathrm{b}_{0}+\mathrm{b}_{1} \mathrm{VPS}+\mathrm{b}_{2} \mathrm{HS}+\varepsilon
$$

dimana :

$$
\begin{array}{ll}
\text { BAS } & =\text { Bid-Ask Spread } \\
\text { VPS } & =\text { Volume Perdagangan Saham } \\
\text { HS } & =\text { Harga Saham } \\
\mathrm{b}_{0} & =\text { Konstanta } \\
\mathrm{b}_{1^{\prime}} \mathrm{b}_{2} & =\text { Koefisien regresi } \\
\varepsilon=\text { Kesalahan pengganggu (disturbance term) }
\end{array}
$$

Sebelum dilakukan pembahasan, terlebih dahulu diuji asumsi yang mendasari model regressi berganda dengan melakukan: (1) Uji Normalitas, (2) Uji Multikolinearitas, (3) Uji Autokorelasi, (4) Uji Heteroskedastisitas. Setelah asumsi klasik diuji, maka selanjutnya dilakukan uji $\mathrm{F}$ dan uji $\mathrm{t}$. 
Menurut Ghozali (2005:84), Uji statistik F pada dasarnya menunjukkan apakah semua variabel independen yang dimaksud dalam model mempunyai pengaruh secara bersama-sama terhadap variabel dependen, dengan kriteria sebagai berikut: terima Ho jika Fhitung $\leq$ Ftabel pada $\alpha: 5 \%$ dan tolak Ho jika Fhitung $>$ Ftabel pada $\alpha: 5 \%$

Menurut Jigiyanto (2004:174), uji t digunakan untuk menunjukkan seberapa jauh pengaruh satu variabel independen terhadap variabel dependen. Uji ini digunakan untuk mengetahui tanda koefisien arah regresi masing-masing variabel bebas sehingga dapat ditentukan arah pengaruh volume perdagangan daham dan harga saham terhadap bid-ask spread, dengan kriteria sebagai berikut: Ho diterima jika : t-hitung $\leq \mathrm{t}$ tabel dan tolak Ho ditolak jika : t-hitung > t-tabel

\section{Hasil Penelitian}

\section{HASIL PENELITIAN DAN PEMBAHASAN}

Statistik deskriptif variabel-variabel penelitian, yaitu: Volume Perdagangan Saham (VPS), Harga Saham (HS) dan Bid-Ask Spread (BAS) ditunjukkan pada Tabel 1 berikut:

Tabel 1

Statistik Deskriptif Volume Perdagangan Saham (VPS), Harga Saham (HS) dan Bid-Ask Spread (BAS)

\begin{tabular}{|l|r|r|r|r|r|}
\hline & \multicolumn{1}{|c|}{ N } & Minimum & Maximum & \multicolumn{1}{c|}{ Mean } & Std. Deviation \\
\hline VPS & 7411 & 100 & 1037026400 & 12940122.52 & 7123220.7 \\
HS & 7411 & 52 & 338000 & 9500.14 & 26887.560 \\
BAS & 7411 & .00025 & .37624 & .0227461 & .01577597 \\
Valid N & 7411 & & & & \\
(listwise) & & & & & \\
\hline
\end{tabular}

Sumber : Hasil Pengolahan Data SPSS

Berdasarkan Tabel 1 dapat dikemukakan bahwa rata-rata volume perdagangan saham (VPS) selama periode pengamatan sebesar 12.940.122,52 dengan standar deviasi sebesar 7.123.220,7. Hasil penelitian tersebut menunjukkan bahwa nilai standar deviasi < rata-rata volume perdagangan saham. Hal ini menunjukkan bahwa variabel volume perdagangan saham mengindikasikan hasil yang baik, karena standar deviasi yang mencerminkan penyimpanan dari data variabel tersebut cukup rendah karena lebih kecil dari rata-ratanya.

Variabel harga saham (HS) mengidikasikan hasil kurang baik sebab mencerminkan penyimpangan yang cukup tinggi, dimana standar deviasi > meannya. Variabel bid-ask spread (BAS) mengindikasikan hasil yang cukup baik karena standar deviasi < mean dengan nilai standar deviasi sebesar 0,01557597 dan nilai mean sebesar 0,0227461.

\section{Pengujian Asumsi Klasik}

Menurut Ghozali (2002) uji normalitas dilakukan untuk mengetahui apakah dalam sebuah model regresi bahwa variabel dependen dan independen memiliki distribusi normal atau tidak. Dalam pengujian normalitas digunakan normal P-P Plot Of Regression Standardized Residual sebagaimana ditunjukkan pada Gambar 1 berikut: 


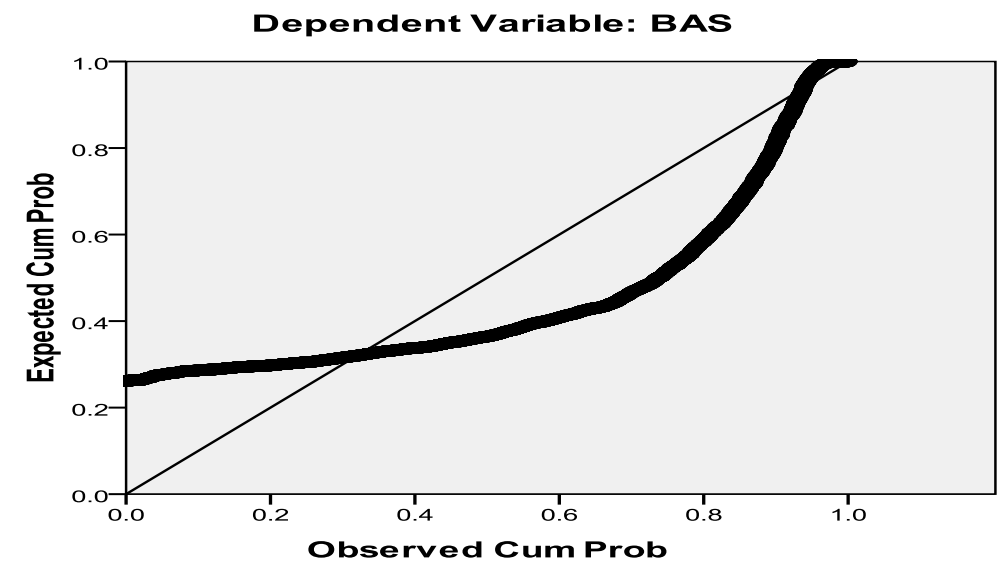

Gambar 1. Normal Probabilty Plot.

Berdasarkan Gambar 1 dapat disimpulkan bahwa data yang teliti tidak berdistribusi normal, oleh karena itu, data ditransformasi dalam bentuk Logaritma Natural (Ln) sebagaimana ditunjukkan pada Gambar 2 berikut :

Dependent Variable: Ln_BAS

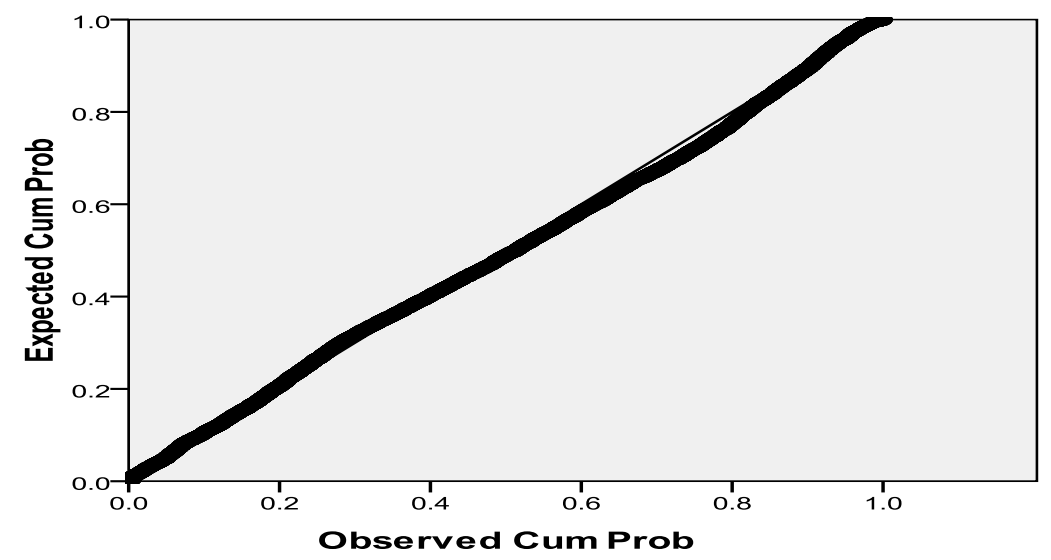

Gambar 2. Normal Probability Plot.

Berdasarkan Gambar 2 tersebut dapat dikemukakan bahwa data telah berdistribusi normal. Selanjutnya, uji multikolinearitas dilakukan untuk mengetahui adanya korelasi antara variabel independen dalam suatu model regresi dengan memperhatikan nilai Variance Inflation Factor (VIF) sebagaimana ditunjukkan pada Tabel 2 berikut:

\section{Tabel 2. Hasil Uji Multikolinearitas}

Coefficients $^{\mathrm{a}}$

\begin{tabular}{|ll|r|r|}
\hline \multirow{2}{*}{\multicolumn{1}{|c|}{ Model }} & \multicolumn{2}{|c|}{ Collinearity Statistics } \\
\cline { 2 - 3 } & Tolerance & \multicolumn{1}{|c|}{ VIF } \\
\hline $1 \quad$ (Constant) & 1.000 & 1.000 \\
Ln_VPS & 1.000 & 1.000 \\
\hline
\end{tabular}

a. Dependent Variable: Ln_BAS

Sumber : Hasil Pengolahan Data SPSS 20

Dari Tabel 2 diperoleh hasil bahwa nilai VIF $<5$, sehingga dapat di simpulkan tidak terjadi multikolinearitas diantara kedua variabel bebas. 
Heteroskedastisitas diuji dengan menggunakan uji metode Grafik, yaitu dengan melihat ada tidaknya pola tertentu yang tergambar pada scatterplot (Umar, 2008) sebagaimana ditunjukkan pada Gambar 2 berikut.

\section{Dependent Variable: Ln_BAS}

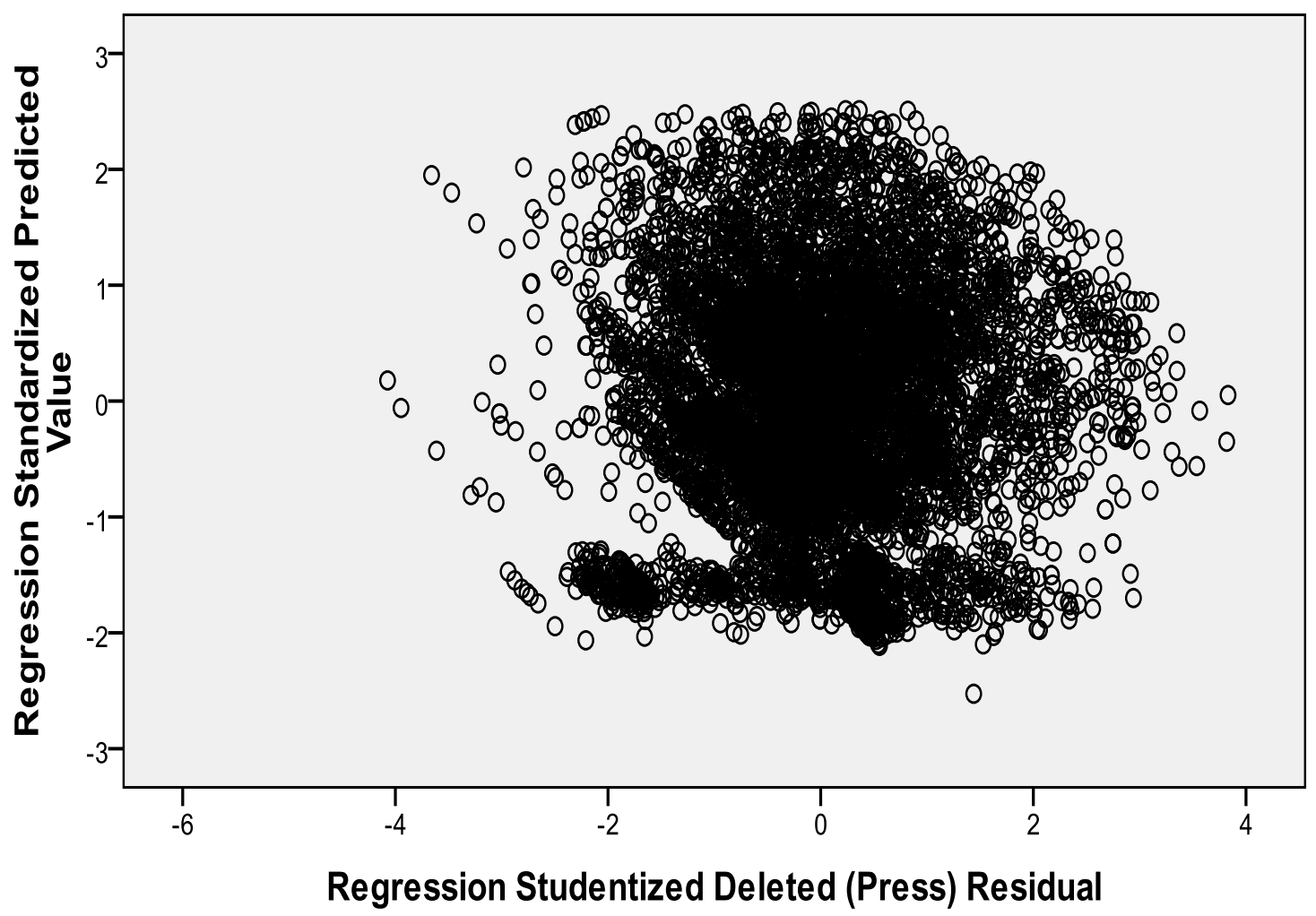

Gambar 2. scatterplot

Gambar 2 tersebut mengindikasikan tidak terdapat pola tertentu seperti (bergelom bang melebar kemudian menyempit) dan tidak ada suatu pola yang jelas serta titik-titik menyebar diatas dan dibawah angka 0 pada sumbu $\mathrm{Y}$ sehingga dapat dinyatakan tidak terjadi heteroskedastisitas.

Uji autokorelasi dilakukan dengan mempergunakan Uji Durbin-Watson sebagaimana ditunjukkan pada Tabel 3 berikut:

Tabel 3. Hasil Uji Autokorelasi Model Summaryb

\begin{tabular}{|l|c|r|r|r|r|}
\hline Model & $\mathrm{R}$ & R Square & Adjusted R Square & Std. Error of the Estimate & Durbin-Watson \\
\hline 1 & $.691^{\mathrm{a}}$ & .477 & .477 & .86418 & 1.127 \\
\hline
\end{tabular}

a. Predictors: (Constant), Ln_VPS, Ln HS

b.Dependent Variable: Ln_BAS

Sumber : Hasil Pengolahan Data SPSS 20

Dari Tabel 3 di atas menunjukan nilai Durbin-Watson sebesar 1,127 berada diantara 2 sampai dengan +2 sehingga dapat disimpulkan tidak terjadi autokorelasi.

Pengujian Hipotesis 
Dari pegujian asumsi klasik dapat disimpulkan bahwa data yang diteliti telah berdistibusi normal, tidak terdapat multikolinearitas, autokorelasi, dan heteroskedastisitas, sehingga memenuhi persyaratan untuk melakukan pengujian atas hipotesis. Pengujian dimaksudkan untuk mengetahui pengaruh variabel volume perdagangan saham (VPS) dan harga saham (HS) terhadap bid-ask spread (BAS). Hasil rekapitulasi perhitungan statistik dapat dilihat pada Tabel 4.

Tabel 4. Rekapitulasi Hasil Penelitian Pengaruh Volume Perdagangan Saham dan Harga Saham Terhadap Bid-Ask Spread

Dependen Variabel : Bid-Ask Spread (BAS)

Independen Variabel: Volume Perdagangan Saham (VPS) dan Harga Saham (HS)

Metode: Least Square

Observasi: 7411

$\mathrm{BAS}=\alpha+\beta_{1} \mathrm{VPS}+\beta_{2} \mathrm{HS}+\varepsilon$

\begin{tabular}{|l|c|r|r|r|r|}
\hline \multirow{2}{*}{ Model } & \multicolumn{2}{|c|}{$\begin{array}{c}\text { Unstandardized } \\
\text { Coefficients }\end{array}$} & $\begin{array}{c}\text { Standardized } \\
\text { Coefficients }\end{array}$ & \multirow{2}{*}{ t-Statistic } & \multirow{2}{*}{ Sig. } \\
\cline { 2 - 4 } & B & Std.Error & \multicolumn{1}{c|}{ Beta } & \\
Konstanta & $-0,568$ & 0,049 & & $-11,511$ & 0,000 \\
VPS & $-0,195$ & 0,003 & $-0,556$ & $-66,147$ & 0,000 \\
HS & $-0,237$ & 0,005 & $-0,412$ & $-48,987$ & 0,000 \\
\hline R Multipel & 0,691 & F-Statistic & & $3380,050,000$ \\
R Square & 0,477 & Sig. & \\
Adjusted R Square & 0,477 & & & \\
Std. Error of the Estimate & 0,8641 & & & \\
\hline
\end{tabular}

Sumber: Hasil Olahan Data Penelitian dengan Mempergunakan Program SPSS.

Berdasarkan Tabel 4 dapat diketahui bahwa secara bersama-sama variabel volume perdagangan saham (VPS) dan harga saham (HS) berpengaruh signifikan terhadap bid-ask spread (BAS). Hal ini ditunjukkan oleh nilai signifikansi uji F sebesar 0,000 yang lebih kecil dari tingkat signifikannya yaitu 0,05 .

Selanjutnya, pengaruh volume perdagangan saham (VPS) dan hara Saham (HS) secara parsial terhadap bid-ask spread (BAS) dapat dikemukakan bahwa variabel volume perdagangan saham (VPS) berpengaruh negatip dan signifikan terhadap bid-ask spread (BAS) dengan nilai koefisien regressi adalah -0,195 dan probabilitas sebesar 0,000. Koefisien regressi variabel harga saham (HS) sebesar -0,237 dengan probabilitas sebesar 0,000. Artinya, bahwa harga saham (HS) berpengaruh negatip dan signifikan terhadap bid-ask spread (BAS).

Kemudian dalam penelitian ini dilakukan pengelompokan data untuk mengetahui apakah setelah ada pengelompokkan data hasil yang di dapatkan sama dengan sebelum data kelompokkan. Bentuk pengelompokan data yang digunakan adalah berdasarkan hasil rata-rata dari volume perdagangan saham.

Dengan melakukan pengelompokan data berdasarkan rata-rata volume perdagangan (dibawah dan diatas rata-rata volume perdagangan saham) rekapitulasi hasil penelitian dapat dilihat pada Tabel 5 dan 6 berikut. 
Tabel 5. Rekapitulasi Hasil Penelitian Pengaruh Volume Perdagangan dan Harga Saham Terhadap Bid-Ask Spread (dibawah rata-rata)

\begin{tabular}{|c|c|c|c|c|c|}
\hline \multicolumn{6}{|c|}{$\begin{array}{l}\text { Dependen Variabel : Bid-Ask Spread (BAS) } \\
\text { Independen Variabel: Volume Perdagangan Saham (VPS) dan Harga Saham (HS) } \\
\text { Metode: Least Square } \\
\text { Observasi: } 6813 \\
\text { BAS }=\alpha+\beta_{1} \text { VPS }+\beta_{2} H S+\varepsilon\end{array}$} \\
\hline \multirow[t]{2}{*}{ Model } & \multicolumn{2}{|c|}{$\begin{array}{l}\text { Unstandardized } \\
\text { Coefficients }\end{array}$} & $\begin{array}{c}\text { Standardized } \\
\text { Coefficients }\end{array}$ & \multirow[t]{2}{*}{ t-Statistic } & \multirow[t]{2}{*}{ Sig. } \\
\hline & $\mathrm{B}$ & Std.Error & Beta & & \\
\hline Konstanta & $-0,294$ & 0,054 & & $-5,447$ & 0,000 \\
\hline VPS & $-0,240$ & 0,005 & $-0,420$ & $-47,806$ & 0,000 \\
\hline HS & $-0,220$ & 0,004 & $-0,545$ & $-61,997$ & 0,000 \\
\hline \multicolumn{2}{|l|}{ R Multipel } & 0,689 & \multicolumn{2}{|l|}{ F-S } & 3076,69 \\
\hline \multicolumn{2}{|l|}{ R Square } & 0,475 & \multicolumn{2}{|l|}{ Sig. } & 0,000 \\
\hline \multirow{2}{*}{\multicolumn{2}{|c|}{ Adjusted R Square }} & 0,475 & & & \\
\hline & & 0,876 & & & \\
\hline
\end{tabular}

Sumber: Hasil Olahan Data Penelitian dengan Mempergunakan Program SPSS.

Tabel 6. Rekapitulasi Hasil Penelitian Pengaruh Volume Perdagangan dan Harga Saham Terhadap Bid-Ask Spread (diatas rata-rata)

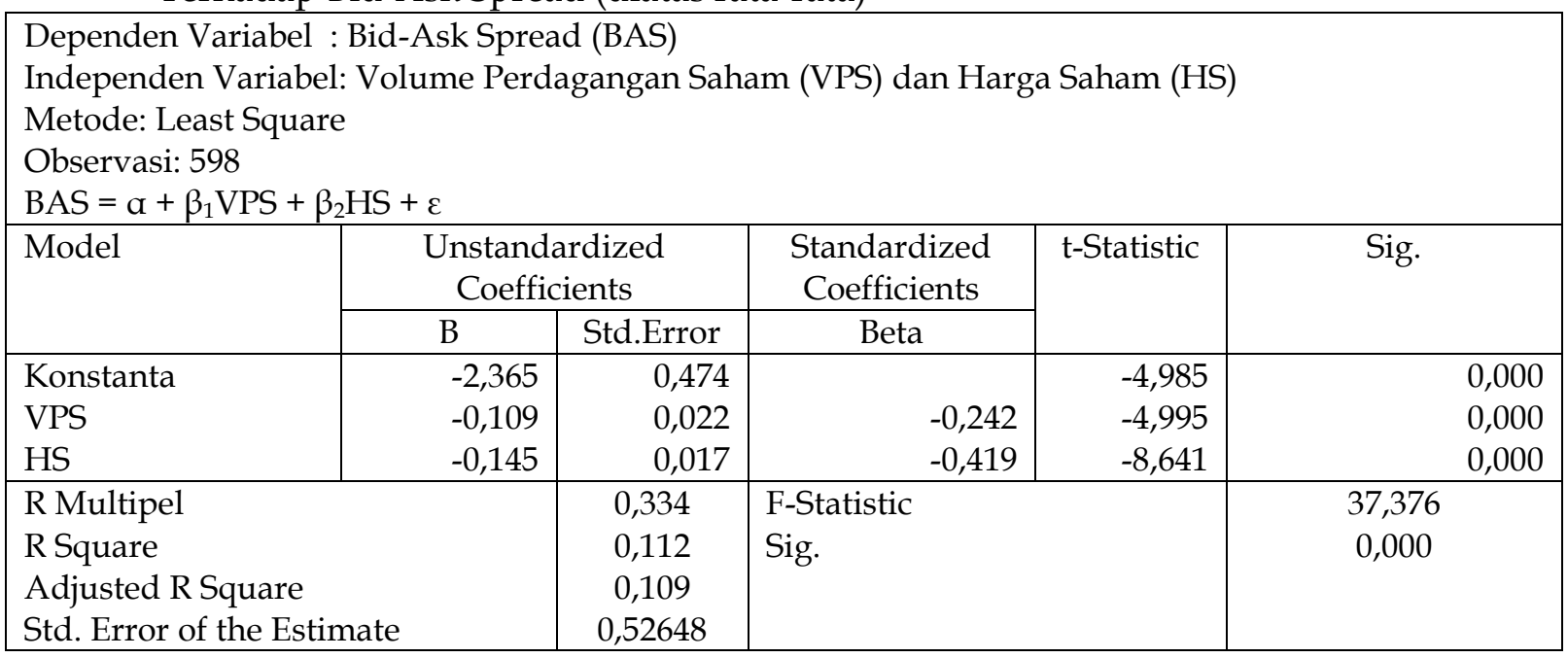

Sumber: Hasil Olahan Data Penelitian dengan Mempergunakan Program SPSS.

Berdasarkan Tabel 5 dan 6 dapat dikemukakan bahwa volume perdagangan saham (VPS) dan harga saham (HS) berpengaruh signifikan terhadap bid-ask spread (BAS) yang ditunjukkan oleh nilai $\mathrm{F}$ hitung dengan probabilitas sebesar 0,000. Selanjutnya, secara parsial, volume perdagangan saham (VPS) dan harga saham (HS) berpengaruh negatip dan signifikan terhadap bid-ask spread (BAS) yang ditunjukkan oleh nilai $t$ hitung dengan probabilitas sebesar 0,000. Koefisien arah pengaruh volume perdagangan saham (VPS) dan harga saham (HS) terhadap bid-ask spread (BAS) baik sebelum dan sesudah sampel dipisahkan memiliki arah yang sama.

\section{Pembahasan Hasil Penelitian}

Hasil pengujian secara parsial diketahui bahwa variabel volume perdagangan saham berpengaruh negatif dan signifikan terhadap bid-ask spread, dan variabel harga saham juga berpengaruh negatif dan signifikan terhadap bid-ask spread serta dalam pengujian secara simultan bahwa volume perdagangan saham dan harga saham berpengaruh dan signifikan 
terhadap bid-ask spread. Hal ini didukung dari nilai $R$ square sebesar 0,477 yang mengindikasikan bahwa variasi variabel vilume perdagangan dan harga saham dapat menjelaskan variasi variabel bid-ask spread sebesar $47,7 \%$. Sedangkan sisanya sebesar 52,3\% dijelaskan oleh variabel lain. Dengan mempergunakan pendapat Azis (2010), dapat dikemukakan bahwa nilai $\mathrm{R}$ square cukup bagus. Artinya, kemampuan variabel volume perdagangan saham dan harga saham dalam menjelaskan bid-ask spread cukup baik.

\section{Pengaruh Volume Perdagangan terhadap Bid-Ask Spread}

Variabel volume perdagangan saham memiliki pengaruh negatif dan signifikan terhadap bid-ask spread apabila diuji secara parsial, bahkan setelah pengelompokan data berdasarkan volume perdagangan saham dilakukan bahwa volume perdagangan saham tetap berpengaruh negatip terhadap bid-ask spread.

Penelitian ini menunjukan bahwa kenaikan volume perdagangan saham membuat bid-ask spread menjadi rendah sehingga dapat disimpulakan bahwa informasi yang dimiliki oleh investor dalam melakukan aktivitas perdagangan saham-saham perusahaan manufaktur di Bursa Efek Indonesia pada tahun 2015 secara relatif sama, dan aktivitas perdagangan tersebut didominasi oleh investor likuiditas. Selain hal tersebut dapat juga dikemukakan bahwa perdagangan saham Perusahaan Manufaktur di Bursa Efek Indonesia pada tahun 2015 sudah likuid.

Berdasarkan hasil penelitian tersebut dapat dikemukakan bahwa pengaruh negatif volume perdagangan saham terhadap bid-ask spread menggambarkan bahwa investor piawai tidak berperan banyak dalam melakukan aktivitas perdagangan saham di BEI melainkan investor likuiditas lebih yang berperan aktif dalam perdagangan saham, sehingga volume perdagangan saham berpengaruh negatif terhadap spread.

Hasil penelitian ini selaras dengan hasil penelitian yang dilakukan oleh Tanner (1971); Atkins and Dyl (1997); Ambarwati (2003); Magdalena dan Nany (2003); Chabchitrchaidol dan Panyanukul (2005); Ambarwti (2008); Ciptaningsih (2010) serta mendukung teori likuiditas.

\section{Pengaruh Harga Saham Terhadap Bid-Ask Spread}

Variabel harga saham memiliki pengaruh negatif dan signifikan terhadap bid-ask spread baik sebelum maupun sesudah dilakukan pengelompokan sampel penelitian berdasarkan volume perdagangan saham. Harga saham yang semakin tinggi membuat bid-ask spread menjadi rendah sehingga dapat disimpulkan bahwa harga saham yang semakin tinggi tidak mempengaruhi investor untuk melakukan perdagangan pada perusahaan manufaktur di Bursa Efek Indonesia pada tahun 2015.

Berdasarkan hasil penelitian dapat dikemukakan bahwa pengaruh negatif antara harga saham dengan bid-ask spread dikarenakan oleh investor tidak mempertimbangkan harga saham yang tinggi serta investor tidak menggukan teori yang dinyatakan oleh Koewn et al (2010) yaitu" spread akan lebih besar untuk mata uang yang jarang diperdagangkan. Hal ini mengindikasikan bahwa tingginya harga dapat mengurangi permintaan. Sama halnya dengan saham, ketika saham terlalu mahal maka saham tersebut akan jarang diperdagangkan sehingga saham kurang likuid, dan menyebabkan spread membesar karena risiko untuk saham tersebut lebih besar".

Pada penelitian ini disimpulkan bahwa harga saham yang tinggi membuat spread rendah serta menyatakan bahwa perdagangan saham Perusahaan Manufaktur di Bursa Efek Indonesia pada tahun 2015 sudah likuid. Hasil penelitian ini sejalan dengan penelitian yang dilakukan oleh oleh Nany (2003); Chandra (2003) ; Ciptaningsih (2010).

Berdasarkan hasil penelitian ini diharapkan dapat menjadi masukan atau informasi bagi investor, dalam melakukan aktivitas perdagangan saham. Investor sebaiknya memperhatikan volume perdagangan saham dan harga saham sebelum melakukan 
pembelian saham. Investor dapat mempergunakan besaran spread dan volume perdagangan saham dalam menentukan saham-saham yang likuid.

Pasar saham yang likuid disebabkan oleh dua hal, yaitu; mekanisme perdagangan saham dan transfaransi. Berdasarkan hasil penelitian ini dapat dikemukakan bahwa mekanisme perdagangan saham di Bursa Efek Indonesia sangat baik, serta informasi yang didapatkan investor likuiditas dan investor piawai relative sama atau dapat disimpulkan bahwa pasar saham telah transfaran dalam membagikan informasi, seperti; volume perdagangan saham, harga kuotasi, frekuensi perdagangan, dan laporan keuangan yang aktif dipublikasikan oleh perusahaan manufaktur di Bursa Efek Indonesia.

\section{Kesimpulan}

\section{KESIMPULAN DAN SARAN}

Berdasarkan hasil penelitian yang telah diuraikan sebelumnya dapat dibuat kesimpulan sebagai berikut : Pertama, Volume perdagangan saham memiliki pengaruh negatif dan signifikan terhadap bid-ask spread, baik sebelum pengelompokan data maupun setelah pengelompokan data dilakukan. Kedua, Harga saham memiliki pengaruh negatif dan signifikan terhadap bid-ask spread, baik sebelum pengelompokan data maupun sesudah pengelompokan data dilakukan. Ketiga, Volume perdagangan saham dan harga saham secara simultan berpengaruh dan signifikan terhadap bid-ask spread, baik sebelum pengelompokan data maupun setelah pengelompkan data dilakukan.

\section{Saran}

Sesuai dengan kesimpulan diatas maka dikemukakan saran sebagai berikut: Pertama, investor sebaiknya memperhatikan besaran bid-ask spread dan volume perdagangan dalam melakukan investasi saham. Kedua, bagi peneliti berikutnya disarankan untuk menggunakan sampel penelitian yang lebih besar dan tahun yang digunakan lebih panjang sehingga dapat memberikan hasil yang lebih akurat. Selanjutnya, peneliti berikutnya disarankan untuk menambah dan mengembangkan faktor-faktor lain yang diduga berpengaruh terhadap bid-ask spread seperti tingkat bunga deposito, return saham dan risiko pasar (beta). Ketiga, perusahaan disarankan untuk melakukan stock split agar dapat diperdagankan dengan harga yang normal.

\section{DAFTAR PUSTAKA}

Afriyanti, Monalisa. 2011. Analisis Pengaruh Dividen Yield, Volume Perdagangan, Ukuran Perusahaan dan Harga Saham Terhadap Bid-Ask Spread Pada Perusahaan Yang Terdaftar Di Bursa Efek Indonesia,Universitas Sumatera Utara, Medan.

Agus, Sartono, 2001. Manajemen Keuangan Teoridan Aplikasi. Yogyakarta: BPEF-Yogyakarta.

Aida Ainul Mardiyah, Mei 2002. "Pengaruh Informasi Asimetri dan Disclosure terhadap Cost of Capital", Jurnal Riset Akuntansi Indonesia, Vol.5 No.2, hal 229-256.

Aitken, Michael dan Alex Frino. 1996. The determinant of market bid-ask on the australian stock exchange: cross sectional analysis, Journal of Accounting and Finance, 36, May.

Ambarwati, Sri Dewi Ari, 2008, Pengaruh Return Saham, Volume Perdagangan Sahamdan Varian Return Saham Terhadap Bisk-Ask Spread Saham Pada Perusahaan Manufaktur yang Tergabung dalam Indeks LQ 45 Periode 2003- 2005,Jurnal Siasat Bisnis, Vol 12, No 1, April, 27-38.

Amihud, Yakov, and H. Mendelson, 1986.Asset Pricing and The Bid-Ask Spread. Journal of Financial Economics, Vol 17, 223-249.

Ang, Robert (1997), BukuPintarPasar Modal Indonesia,Mediasoft Indonesia.Jakarta. 
Anoraga, Pandji, dan Pakarti Piji. 2001. Pengantar Pasar Modal. Edisi Revisi. PT Asdi Mahasatya. Jakarta.

Arifin, Zainal. 2005. "Teori Keuangandan Pasar Modal" Edisi Pertama, Penerbit Ekonisia, Yogyakarta.

Atkins, A. B., and Dyl, E. A. 1997.Transaction costs and Holding Period for common stocks. The Journal of Finance, III(1): 309-325.

Azis, Musdalifah,201. Analisis Jalur, Universitas Mulahrahman, Samarinda.

Balduzzi, Pierluigi, Elton, Edwin J, and Green, Tclifton (2001).Economics News and Bond Prices : Evidence From The US Treasury Market. Journal of Financial and Quantitative analysis, 36, 523 .

Bodie, Zvi, Alex Kane dan Alan J. Marcus. 2006. Investments. Buku 1 dan 2, Terjemahan.

Chabchitrchaidol, Akkharaphol dan Sakkapop Panyanukul, 2005. Key determinants of liquidity is the Thai bond market, Working paper, bank of Thailand, Thailand.

Chandra, Ardha, 2003. "Pengaruh Harga Saham, Volume Perdagangan, dan Volatilitas Harga Saham Terhadap Bid-Ask Spread pada Perusahaan yang melakukan Stock Split di Bursa Efek Indonesia Periode 1999 - 2002", Tesis, Universitas Diponegoro, Semarang.

Ciptaningsih, Agung Nur Isra, 2010. "Analisis Pengaruh Harga Saham, Volume Perdagangan, dan Variansi Return Saham Terhadap Bid-Ask Spread pada Masa Sebelum dan Sesudah Stock Split pada Perusahaan Manufaktur di Bursa Efek Indonesia Periode 2006 - 2009", Skripsi, UniversitasDiponegoro, Semarang.

Demsetz, Harold (1968); TheCost of Transacting; Quarterly Journal of Economics; Vol. 82, No.1; pp. $33-53$.

Fabozzi, Frank, J and Franco Modigliani, 1996 Capital Market, Second Edition. New Jersey Printice - Hall inc.

Fatmawati, Sri dan Marwan, A. 1999. "Pengaruh Stock Split terhadap Likuiditas Saham yang Diukur dengan Besarnya Bid-Ask Spread di Bursa Efek Jakarta",Jurnal Ekonomi dan Bisnis Indonesia, Vol.4, Hal.93-110.

Fleming, Michael J and Eli M. Remolona, 1997. What moves the bond market?, FRBNY Economic policy review.

Ghozali, Imam. 2005. Aplikasi Analisis Multivariate dengan Program SPSS,.Edisi Kedua. Badan Penerbit Universitas, Semarang.

Greenstein, M., dan H. Sami. 1994. The Impact of The SEC's Segment Disclosure Requirement on Bid-Ask Spreads. Accounting Review 69, Januari, 179-199.

Hanafi, Mamduh M. 2004, Manajemen Keuangan. Yogyakarta: BPFE.

Harris, Larry.2003. Trading and Exchanges : market microstructure for practiones. Oxford Univrsity Press.

Hasbrouck, Joel (2007); Empirical Market Microstructure: The Institutions, Economics, and Econometrics of Securities Trading; Oxford University Press.

Husnan, Suad. 1998. Dasar-dasarTeoriPortofoliodanAnalisisSekuritas. EdisiKedua. UPP-AMP YKPN.Yogyakarta.

Keown, et al, 2000.Dasar-dasar Manajemen Keuangan, Buku Kedua, Edisi Pertama, Alih Bahasa Chaerul Djakmandan Sulistryatini, Salemba Empat, Jakarta. 
Krinsky, Itzhak and Jason Lee (1996); Earnings Annoucements and the Components of the BidAsk Spread; Journal of Finance, Vol. 51, No. 4; pp. 1523 - 1535.

Lubis, Fifi Swanti,2013. Pengaruh return saham, volume perdagangan saham, dan volatilitas harga saham erhadap bid ask spread padaperusahaan manufaktur yang melakukan stock split di Bursa Efek Indonesia periode Januari 2010-Oktober 2012. Universitas Sumatera Utara, Medan.

Magdalena Nany dan M. Abdul Aris. 2004. Pengujian Stabilitas Struktural Pengaruh Harga Saham, Return Saham, Varian Return sahamdan Volume Perdagangan Terhadap Bid Ask Spread Pradan Pasca Laporan Keuangan. Jurnal Empirika.

Nany, Magdalena, 2003. "Analisis Pengaruh Harga Saham, Return Saham, Varian Return Saham, Earnings dan Volume Perdagangan Saham terhadap Bid Ask Spread Pradan Pasca Pengumuman Laporan Keuangan".Tesis, Universitas Diponegoro, Semarang.

Napitupulu, Veronica, 2013. "Pengaruh Return Saham, Volume Perdagangan dan Volatilitas Harga Saham terhadap Bid Ask Spread pada Perusahaan yang melakukaan Stock Split di Bursa Efek Indonesia",Skripsi, Universitas Sumatera Utara.

O’Hara, Maureen (1995); Market Microstructure Theory; Blackwell Business.

Silalahi, Donalson, 2008. Determinant Bid-ask Spread :studi pada obligasi Korporasi Yang Telah Diperdagangkan Di Pasar Obligasi Indonesia Periode Tahun 2003-2006 Majalah Media Unika No 72 TH 20, 277-287.

Stoll , Hans R.,(1989). Infering the conponents of the bid ask spread: Theory and empirical tests, journals of finance 44 .

Sugiyono, 2010. Metode Penelitian Kuantitatif Kualitatif dan REB. CV.Alfabeta. Bandung.

Sutrisno, 2000. "Manajemen Keuangan". Ekonosia. Yogyakarta.

Tandelilin, Eduardus. 2001. Analisis Investasi dan Manajemen Portofolio. Edisi Pertama. BPFE.Yogyakarta.

Tanner, J. Ernest, and Levis A. Kochin, 1971.The determinants of the difference between bid-ask spread prices on government bonds, The Journals of Buisnees 44, 375-380.

Yuliastari, Tanti. 2008. Analisis Faktor-Faktor yang Mempengaruhi Bid Ask Spread Sebelum dan Sesudah Stock Split di Bursa Efek Jakarta.Tesis. Program Pasca Sarjana Magister Manajemen. Universitas Diponegoro. Semarang. 